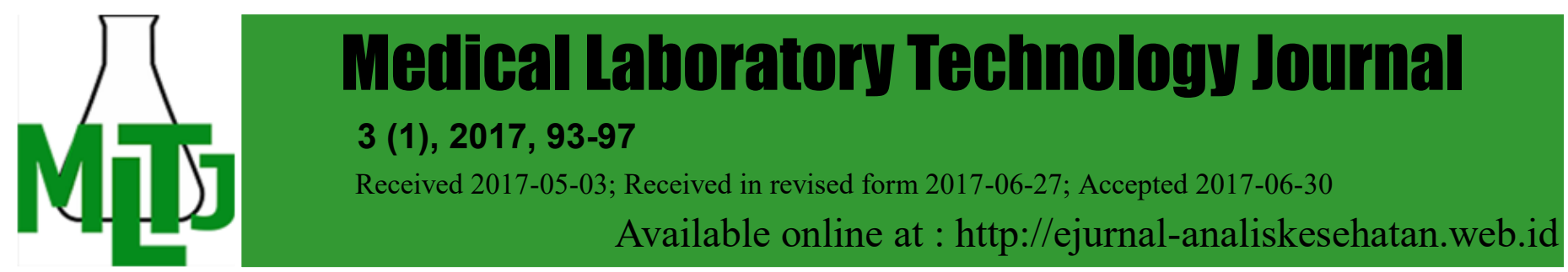

\title{
DAYA BUNUH EKSTRAK AIR DAUN SALAM (Syzygium polyanthum) TERHADAP LARVA Aedes sp.
}

\author{
Ratih Dewi Dwiyanti, Rion Dediq, Anny Thuraidah
}

\author{
Jurusan Analis Kesehatan Poltekkes Kemenkes Banjarmasin \\ JI Mistar Cokrokusumo 4a Banjarbaru \\ e-mail: Ratihdewi262@yahoo.co.id
}

\begin{abstract}
Aedes $\mathrm{sp}$ is known as a mosquito that transmits various diseases. In addition to spreading dengue fever and chikungunya, these mosquitoes also spread the virus zika is quite dangerous. One of the effort to controlling these diseases is to eradicate the vector by using materials that can be taken from plants one of them is bay leaf (Syzygium polyanthum). The purpose of this study is to determine the kills power of Syzygium polyanthum water extract against Aedes sp larvae. This research uses true experiment with Posttest Only With Control Group Design design. Data were obtained from the number of larval deaths in the Syzygium polyanthum extract in each control group and treatment group for 24 hours. The results showed that the percentage of bayleaf water extract which has the largest number of larval deaths was at $32 \%$ concentration with $55 \%$ death percentage. It was concluded that each concentration of aqueous bay leaf water extract given had a killing power against Aedes sp larvae with the lowest percentage of $2.5 \%$ and the highest $55 \%$. Based on the result of Kruskal-Wallis test showed that water extract of the bay leaf was able to kill Aedes sp larvae at each treatment with the value of sig 0,001 . Suggestion for the next researcher to test the power of killing the water extract of Syzygium polyanthum to Aedes sp larvae by increasing the concentration of salted bay water extract.
\end{abstract}

Keywords: Syzygium polyanthum; larvae Aedes sp

Abstrak: Aedes sp dikenal sebagai nyamuk yang menularkan berbagai macam penyakit. Selain menyebarkan penyakit demam berdarah dan chikungunya, nyamuk ini juga menyebarkan virus zika yang cukup berbahaya. Upaya yang dilakukan untuk mengatasi penyakit tersebut antara lain melakukan pemberantasan vektor dengan menggunakan bahan yang dapat diambil dari tumbuhan salah satunya daun salam (Syzygium polyanthum). Tujuan penelitian ini yaitu untuk mengetahui daya bunuh ekstrak air daun salam (Syzygium polyanthum) terhadap larva Aedes sp. Penelitian ini menggunakan true experiment dengan rancangan Posttest Only With Control Group Design. Data diperoleh dari jumlah kematian larva dalam pemberian ekstrak air daun salam (Syzygium polyanthum) pada masing-masng kelompok kontrol dan kelompok perlakuan selama 24 jam. Hasil penelitian menunjukkan bahwa persentase pemberian ekstrak air daun salam yang memiliki jumlah kematian larva terbesar adalah pada konsentrasi 32\% dengan persentase kematian 55\%. Disimpulkan bahwa setiap konsentrasi ekstrak air daun salam yang diberikan memiliki daya bunuh terhadap larva Aedes sp dengan persentase terendah 2,5\% dan tertinggi 55\%. Berdasarkan hasil uji Kruskallwallis menunjukkan bahwa ektrak air daun salam mampu membunuh larva Aedes sp pada masing-masing perlakuan dengan nilai sig 0,001. Saran untuk peneliti selanjutnya melakukan uji daya bunuh ekstrak air daun salam (Syzygium polyanthum) terhadap larva Aedes sp dengan meningkatkan konsentrasi pada ekstrak air daun salam.

Kata kunci: daun salam (Syzygium polyanthum); larva Aedes sp 
PENDAHULUAN

Aedes sp dikenal sebagai nyamuk yang menularkan berbagai macam penyakit. Selain menyebarkan penyakit demam berdarah dan chikungunya, nyamuk ini juga menyebarkan virus zika yang cukup berbahaya (Rona, 2016).

Pada tahun 2015 jumlah kasus DBD di Indonesia mencapai 7.244 kasus dan jumlah kematian dalam rentang waktu tiga bulan mencapai 100 orang (Wahyuni, 2016). Chikungunya dilaporkan mewabah di Bandung pada Desember 2002 dengan ratusan warga terserang kemudian di Jember (Jawa Timur) (Sembel, 2009). Sampai saat ini 18 negara Amerika Latin dan Karibia melaporkan adanya virus zika. Masyarakat Indonesia tetap mewaspadai kemungkinan terinfeksi oleh virus zika ini, mengingat laporan-laporan yang ada selama ini infeksi ini pernah ditemui di Indonesia dan kebetulan vektor pembawa penyakit virus ini yaitu nyamuk Aedes aegypti yang juga membawa penyakit infeksi demam berdarah dan chikungunya (Syam, 2016).

Saat ini belum ada obat yang dapat membunuh virus demam berdarah. Virusnya belum bisa dibasmi sehingga cara memotong rantai penularan penyakit demam berdarah masih tetap hanya dengan cara membasmi nyamuk Aedes-nya. Penyemprotan insektisida memang dapat membunuh nyamuk dewasa seketika, namun jentik nyamuk Aedes-nya tidak binasa. Maka, selama jentik-jentik nyamuk masih tetap hidup diperindukannya, nyamuk Aedes belum terberantas. Itu berarti setiap hari akan terus saja lahir nyamuk baru dan memperbesar kemungkinan masyarakat terjangkit demam berdarah (Nadesul, 2004).

Program pencegahan

pemberantasan DBD belum berhasil menurunkan angka kesakitan DBD cenderung meningkat dengan penyebaran penyakit semakin luas. Pengendalian kimiawi menggunakan insektisida/larvasida sintetik terbukti dapat mengakibatkan keracunan pada manusia, polusi lingkungan bahkan resistensi serangga target (Cania $B, 2013$ ).

Berdasarkan hal tersebut, maka dibutuhkan usaha untuk mendapatkan bahan alternatif, misalnya dari bahan yang dapat diambil dari tumbuhan. Bahan dari tumbuhan merupakan larvasida alami karena mudah terurai di lingkungan, tidak meninggalkan residu di udara, air, tanah serta relatif lebih aman untuk digunakan (Ervina, 2014).
Hasil penelitian Fitriah (2015) diketahui konsentrasi bubuk daun salam yang paling efektif dalam membunuh larva Aedes $s p$ adalah pada konsentrasi $6,0 \mathrm{gr} / 100 \mathrm{ml}$. Namun penggunaan bubuk dapat meninggalkan residu/kotor pada air. Senyawa yang terkandung dalam daun salam yaitu alkaloid, minyak atsiri, dan tanin diduga dapat memberikan efek larvasida. Hal inilah yang menjadi dasar dilakukannya penelitian daya bunuh ekstrak air daun salam (Syzygium polyanthum) terhadap larva Aedes $s p$. Penelitian ini bertujuan untuk mengetahui daya bunuh ekstrak air daun salam (Syzygium polyanthum) terhadap larva Aedes sp.

\section{BAHAN DAN METODE}

Penelitian ini menggunakan metode eksperimen sebenarnya (true experiment), dengan rancangan eksperimen sederhana (Posttest Only With Control Group Design), yaitu mengukur pengaruh perlakuan pada kelompok eksperimen dengan membandingkan kelompok tersebut dengan kelompok kontrol (Notoatmodjo, 2012). Bahan yang digunakan dalam penelitian ini adalah daun salam spesies Syzygium polyanthum yang sudah dideterminasi dan larva Aedes $s p$. Variabel bebas dalam penelitian ini adalah ekstrak air daun salam dengan konsentrasi $1,0 \mathrm{ml} / 100 \mathrm{ml}, 2,0 \mathrm{ml} / 100 \mathrm{ml}, 4,0 \mathrm{ml} / 100 \mathrm{ml}$, $8,0 \mathrm{ml} / 100 \mathrm{ml}, 16,0 \mathrm{ml} / 100 \mathrm{ml}, 32,0 \mathrm{ml} / 100$ $\mathrm{ml}$. Variabel terikat dalam penelitian ini adalah jumlah larva Aedes sp. yang sudah mati dalam ekstrak air daun salam.

Pembuatan ekstrak air daun salam dengan cara daun salam segar dicuci bersih dengan air mengalir untuk menghilangkan kotoran yang menempel dan dianginanginkan. Kemudian ditimbang sebanyak 150 gr dan dihaluskan dengan cara di blender dalam pelarut aquadest $150 \mathrm{ml}$. Didiamkan selama 1 jam dalam beaker glass yang ditutupi dengan kertas aluminium foil pada suhu kamar dan terlindung dari cahaya. Kemudian air daun salam di peras, disaring dan dimasukkan kedalam beaker glass.

Pembuatan pengenceran dengan menggunakan aquadest : Untuk konsentrasi $1,0 \mathrm{ml} / 100 \mathrm{ml}$, dipipet $1,0 \mathrm{ml}$ ekstrak air daun salam dan ditambahkan aquadest sebanyak $99 \mathrm{ml}$. Untuk konsentrasi $2,0 \mathrm{ml} / 100 \mathrm{ml}$, dipipet $2,0 \mathrm{ml}$ ekstrak air daun salam dan ditambahkan aquadest sebanyak $98 \mathrm{ml}$. 
Pembuatan konsentrasi $4,0 \mathrm{ml} / 100 \mathrm{ml}$, dipipet $4,0 \mathrm{ml}$ ekstrak air daun salam dan ditambahkan aquadest sebanyak $96 \mathrm{ml}$. Untuk konsentrasi $8,0 \mathrm{ml} / 100 \mathrm{ml}$, dipipet 8,0 $\mathrm{ml}$ air daun ekstrak salam dan ditambahkan aquadest sebanyak $92 \mathrm{ml}$. Untuk konsentrasi $16,0 \mathrm{ml} / 100 \mathrm{ml}$, dipipet 16,0 ml ekstrak air daun salam dan ditambahkan aquadest sebanyak $84 \mathrm{ml}$. Untuk konsentrasi 32,0 $\mathrm{ml} / 100 \mathrm{ml}$, dipipet $32,0 \mathrm{ml}$ ekstrak air daun salam dan ditambahkan aquadest sebanyak $68 \mathrm{ml}$. Untuk pembuatan kontrol dipipet aquadest sebanyak $100 \mathrm{ml}$.

Persiapan larva dengan cara larva yang didapat berdasarkan dari pengumpulan telur nyamuk Aedes sp dengan cara ovitrap sampai berubah menjadi larva : Dibuat ovitrap dengan mengisi air pada gelas hitam (setengah penuh). Dimasukkan kertas saring dan biarkan terendam sekitar $1 \mathrm{~cm}$ (atur sedemikian rupa). Diletakkan di tempat gelap dan didiamkan selama lima hari. Setelah lima hari dilihat kertas saring apakah ada telur yang menempel. Diambil satu telur diletakkan di objeck glass tutup dengan cover glass dan periksa di bawah mikroskop. Kertas saring yang terdapat telur nyamuk dimasukkan ke dalam gelas penampung yang telah di isi dengan aquadest (setengah penuh) sampai menjadi larva.

Pengujian ekstrak air daun salam terhadap larva Aedes sp. dengan cara larva Aedes sp yang sudah didapatkan dimasukkan kedalam beaker glass yang sudah berisi air perasan daun salam dengan konsentrasi 1,0 $\mathrm{ml} / 100 \mathrm{ml}, 2,0 \mathrm{ml} / 100 \mathrm{ml}, 4,0 \mathrm{ml} / 100 \mathrm{ml}, 8,0$ $\mathrm{ml} / 100 \mathrm{ml}, 16,0 \mathrm{ml} / 100 \mathrm{ml}$, dan $32 \mathrm{ml} / 100 \mathrm{ml}$. Masing-masing beaker glass diisi 20 ekor larva nyamuk. Kemudian beaker glass tadi ditutup dengan kain kasa dan dibiarkan selama 24 jam. Setelah 24 jam larva nyamuk diamati pada konsentrasi berapa ekstrak air daun salam dapat membunuh larva. Pemeriksaan larva Aedes sp. untuk memastikan larva yang diuji adalah larva Aedes sp. Memipet larva yang terdapat pada beaker glass. Kemudian meletakkan pada objek glass dan ditutup dengan cover glass kemudian diperiksa dibawah mikroskop dengan perbesaran $10 \times 10$. Diamati apakah terdapat sifon yang pendek, jika ada maka dapat dinyatakan larva tersebut adalah larva Aedes sp.

\section{HASIL DAN PEMBAHASAN}

Jumlah Kematian Larva Aedes sp dapat dilihat pada tabel 1 .
Tabel 1 Kematian Larva Aedes sp dalam pemberian eksrak air daun salam (Syzygium polyanthum)

\begin{tabular}{ccccccc}
\hline $\begin{array}{c}\text { Konsentrasi } \\
\text { ekstrak air } \\
\text { daun salam } \\
(\mathrm{ml} / 100 \mathrm{ml})\end{array}$ & $\begin{array}{c}\boldsymbol{c} \\
\text { Larva }\end{array}$ & Ulang 1 & Ulang 2 & Ulang 3 & Ulang 4 & Rerata \\
\hline Kontrol & 20 & 0 & 0 & 0 & 0 & 0 \\
1,0 & 20 & 0 & 0 & 0 & 0 & 0 \\
2,0 & 20 & 0 & 0 & 0 & 0 & 0 \\
4,0 & 20 & 0 & 0 & 0 & 0 & 0 \\
8,0 & 20 & 2 & 0 & 0 & 0 & 0,5 \\
16,0 & 20 & 4 & 3 & 2 & 3 & 3 \\
32,0 & 20 & 13 & 7 & 14 & 10 & 11 \\
\hline
\end{tabular}

Berdasarkan tabel 1 didapatkan grafik persentase rata-rata daya bunuh ektrak air daun salam (Syzygium polyanthum) terhadap larva Aedes sp yang ditunjukkan pada gambar 1 berikut:

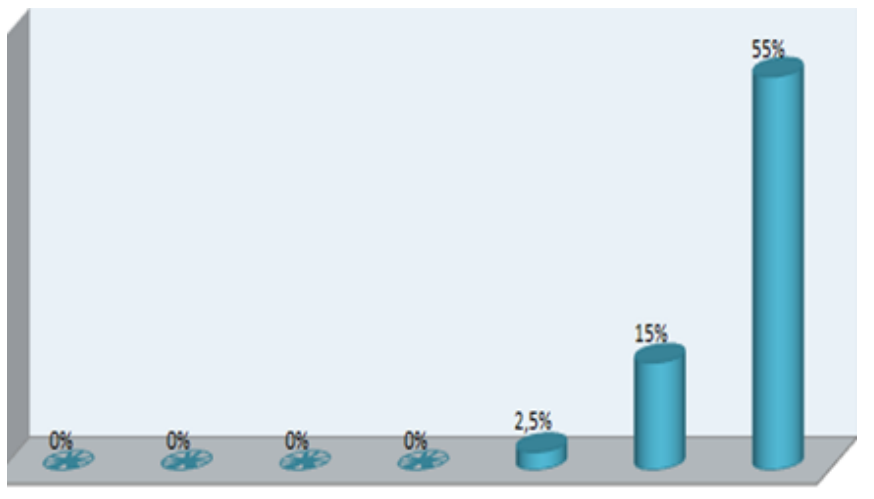

Kontrol $\quad 1 \mathrm{~m} / 100 \mathrm{ml} \quad 2 \mathrm{~m} / 100 \mathrm{ml} \quad 4 \mathrm{~m} / 100 \mathrm{ml} \quad 8 \mathrm{~m} / 100 \mathrm{ml} \quad 16 \mathrm{~m} / 100 \mathrm{ml} 32 \mathrm{~m} / 100 \mathrm{ml}$

Gambar 1 Grafik persentase rata-rata daya bunuh ekstrak air daun salam terhadap larva Aedes sp.

Data yang diperoleh dilakukan analisis statistik dengan uji Kruskal-wallis karena data tidak terdistribusi normal. Hasil menunjukkan nilai signifikansi $0,001 \quad(p<0.05)$. Hal ini menunjukkan bahwa ektrak air daun salam mampu membunuh larva Aedes sp pada masing-masing perlakuan.

Berdasarkan hasil penelitian yang telah dilakukan terhadap jumlah kematian larva $A e-$ des sp setelah pengamatan 24 jam dengan 4 kali pengulangan didapatkan persentase ratarata kematian larva nyamuk pada kontrol, 1,0 $\mathrm{ml} / 100 \mathrm{ml}, 2,0 \mathrm{ml} / 100 \mathrm{ml}, 4,0 \mathrm{ml} / 100 \mathrm{ml}, 8,0$ $\mathrm{ml} / 100 \mathrm{ml}, 16,0 \mathrm{ml} / 100 \mathrm{ml}$, dan $32 \mathrm{ml} / 100 \mathrm{ml}$ masing-masing sebesar $0 \%, 0 \%, 0 \%, 0 \%$, $2,5 \%, 15 \%$, dan $55 \%$. Hal ini menunjukkan bahwa semakin besar konsentrasi ekstrak air daun salam (Syzygium polyanthum) yang diberikan terhadap larva maka semakin meningkat jumlah kematian larva Aedes sp. 
semakin banyak komponen zat yang terkandung dalam daun salam tersebut salah satu kandungan yang memberikan efek paling besar yaitu alkaloid karena dapat menghambat aktifitas enzim asetylcholinesterase yang mempengaruhi transmisi impuls saraf sehingga menyebabkan enzim tersebut mengalami fosforilasi dan menjadi tidak aktif sehingga mortalitas pada larva terganggu.

Kematian larva kemungkinan disebabkan karena adanya zat aktif yang terdapat pada daun salam (Syzygium polyanthum) yaitu alkaloid, minyak atsiri, dan tannin (Mangoting dkk., 2005).

Alkaloid bekerja dengan cara menghambat aktifitas enzim asetylcholinesterase yang mempengaruhi transmisi impuls saraf sehingga menyebabkan enzim tersebut mengalami fosforilasi dan menjadi tidak aktif (Shadana, dkk,. 2014). Enzim asetylcholinesterase adalah suatu enzim yang terdapat di dalam membrane sel pada terminal saraf kolinergik juga pada membrane lainnya seperti dalam plasma darah, sel plasenta yang berfungsi sebagai katalis untuk menghidrolisis acetylcholine menjadi choline dan acetat. Acetylcholine adalah salah satu agen yang terdapat dalam fraksi ujung-ujung saraf dari sistem saraf yang menghambat penyebaran impuls dari neuron ke post ganglionik, cholinesterase sendiri disintesis pada hati (Ganong, 1983 dalam Rustia, 2009).

Tanin dapat mengganggu serangga dalam mencerna makanan karena tanin akan mengikat protein dalam sistem pencernaan, sehingga proses penyerapan protein dalam sistem pencernaan menjadi terganggu (Hagerman, 2002 dalam Hairani, 2014).

Minyak atsiri yang dipakai akan menguap ke udara. Bau ini akan terdeteksi oleh reseptor kimia (Chemoreceptor) yang terdapat pada antena nyamuk dan diteruskan ke impuls saraf. Bau dari minyak atsiri tidak disukai nyamuk (Shinta, 2010 dalam Handayani dkk,. 2013).

Pada penelitian ini diperoleh efek larvasida ekstrak air daun salam dengan konsentrasi yang paling efektif adalah $32 \mathrm{ml} / 100 \mathrm{ml}$ dengan persentase kematian 55\%. Hasil penelitian Fitriah (2015) diketahui konsentrasi bubuk daun salam efektif dalam membunuh larva Aedes sp adalah konsentrasi 6,0 gr/ 100 $\mathrm{ml}(6 \%)$ dengan persentase kematian 100\%. Perbedaan dalam penelitian ini adalah pada penelitian ini melarutkan daun salam pada aquadest hingga mendapatkan konsentrasi $100 \%$ kemudian dilakukan pengenceran pada masing-masing kelompok perlakuan. Adapun senyawa yang terkandung pada daun salam yang dapat larut dalam air yaitu alkaloid dan tanin, sedangkan pada penelitian Fitriah menggunakan daun salam dalam bentuk bubuk yang dilarutkan pada $100 \mathrm{ml}$ air yang kemungkinan senyawa yang terkandung pada daun salam ikut terlarut dalam air.

Beberapa faktor yang dapat mempengaruhi kematian larva yaitu indikator suhu, kelembaban, derajat keasaman dan salinitas (Zuldarisman, 2013).

\section{KESIMPULAN}

Ekstrak air daun salam (Syzygium polyanthum) konsentrasi $8,0 \mathrm{ml} / 100 \mathrm{ml}, 16,0$ $\mathrm{ml} / 100 \mathrm{ml}$, dan $32 \mathrm{ml} / 100 \mathrm{ml}$ mempunyai daya bunuh terhadap larva Aedes $s p$ berdasarkan hasil uji Kruskall-wallis dengan nilai sig 0,001. Konsentrasi daya bunuh ekstrak air daun salam terhadap larva Aedes $s p$ yaitu: Konsentrasi terkecil dari ekstrak air daun salam dalam membunuh larva Aedes $s p$ adalah $8,0 \mathrm{ml} / 100 \mathrm{ml}$ dengan persentase kematian sebesar 2,5\%. Konsentrasi terbesar dari ekstrak air daun salam dalam membunuh larva Aedes sp adalah 32,0 ml/100 ml dengan persentase kematian sebesar $55 \%$.

\section{SARAN}

Melakukan uji daya bunuh ekstrak air daun salam (Syzygium polyanthum) terhadap larva Aedes sp dengan menggunakan metode ektraksi lain. Melakukan uji daya bunuh pada larva spesies lain misalnya Anopheles sp, Culex sp, dan Mansonia sp. Melakukan uji daya bunuh Aedes sp dengan menggunakan bahan alami atau tumbuhan lain.

\section{DAFTAR PUSTAKA}

Cania, E. (2013). Uji efektivitas larvasida ekstrak daun legundi terhadap larva Aedes aegypti. Jurnal Penelitian Universitas Lampung, 2(4).

Ervina, N. (2014). Uji Ekstrak Etanol Daun Singkong sebagai Larvasida Aedes aegypti. Universitas Tanjung Pura Pontianak.

Fitriah. (2015). Efektifitas Bubuk Daun Salam Sebagai Larvasida Terhadap Larva Nyamuk Aedes spp. Universitas Haluoleo Kendari.

Hairani, S. (2014). Efektivitas ekstrak daun mundu sebagai larvasida nyamuk Culex quinquefasciatus dan Aedes aegypti. Fakultas Kedokteran Hewan Institut Pertanian Bogor. 
Handayani. (2013). Efektivitas ekstrak daun sirih sebagai bioinsektisida terhadap kematian nyamuk Aedes aegypti. Universitas Hasanuddin Makkasar.

Nadesul, H. (2004). 100 Pertanyaan dan Jawaban Demam Berdarah. Jakarta: Buku Kompas.

Notoatmodjo, P. D. S. (2012). Metode Penelitian Kesehatan. Jakarta: Rineka Cipta.

Rona. (n.d.). Gejala Ringan, Tapi Butuh Ekstra Perhatian.

Rustia, H. (2009). Pengaruh Pajanan Pestisida Golongan Organofosfat Terhadap Penurunan Aktivitas Enzim Cholinesterase dalam Darah Petani Sayuran Penyemprot Pestisida. Depok: Universitas Indonesia.

Sembel, D. (2009). Entomologi Kedokteran. Yogyakarta: Andi Offset.

Shadana. (2013). Efek Larvasida Ekstrak Etanol Daun Pepaya (Carica papaya) Terhadap Larva Aedes aegypti. Universitas Riau.

Syam, A. (n.d.). Waspadai Virus Zika Berjangkit di Indonesia.

Wahyuni, T. (n.d.). Indonesia Belum Bebas Demam Berdarah.

Zuldarisman. (2013). Efektivitas Air Perasan Buah Belimbing Wuluh (Averrhoa Bilimbi L) Terhadap Kematian Larva Aedes Aegypti dan Larva Anopheles Subpictus. Universitas Hasanuddin Makassar. 